\title{
Enhancing Islamic Students' Reading Comprehension through Predict Organize Search Summarize Evaluate Strategy
}

Received: $14^{\text {th }}$ February 2017; Revised:22 ${ }^{\text {th }}$ February 2017; Accepted: $31^{\text {th }}$ March 2017

Permalink/DOI: http://dx.doi.org/10.15548/jt.v24i1.265

\section{Darmayenti *) \\ Institut Agama Islam Negeri Imam Bonjol \\ Padang, Indonesia \\ E-mail: darmayentid@yahoo.com}

\section{Martin Kustati}

Institut Agama Islam Negeri Imam Bonjol

Padang, Indonesia

E-mail: martinkustati@yahoo.com

*) Corresponding Author

\begin{abstract}
This paper is a report of an experimental research project conducted in a reading comprehension course for firstyear students of the Adab Faculty of the State Institute for Islamic Studies Imam Bonjol Padang, West Sumatera, Indonesia, during the academic year 2015/2016. The "Predict Organize Search Summarize Evaluate" (POSSE) is one strategy that can enhance students' comprehension in reading. Two classes of Arabic and History students chosen through cluster random sampling technique were used as the sample of the research. Reading tests were used to collect the data which was given to both of classes on pre-test and post-test. The result of the research showed that the implementation of Predict Organize Search Summarize Evaluate strategy gave a significant difference in term of the students-learning outcome between the students who were taught through POSSE strategy and by traditional one. The finding of the study showed that teaching reading by using POSSE strategy gave significant effect towards students' reading comprehension. This strategy could improve the students' reading component on finding topic. It can be concluded that using POSSE Strategy has improved Indonesian students' reading comprehension. It is also recommended for English lecturers use POSSE strategy as one of teaching strategies for reading comprehension.
\end{abstract}

Keywords: Predict organize search summarize evaluate strategy, reading, comprehension

How to Cite: Darmayenti. \& Kustati, M. (2017). Enhancing Islamic students' reading comprehension through predict organize search summarize evaluate strategy. Al-Ta Lim Journal, 24(1). doi:http://dx.doi.org/10.15548/jt.v24i1.265

\section{INTRODUCTION}

Mastering reading comprehension is as one of requirements for the first and the second semester students at State Institute for Islamic Studies Imam Bonjol Padang in learning English as one of compulsory subjects. Many reading materials that they use for learning are written in English. In order to get more information for their learning process, they need to be able to read English texts in various genre texts.

Reading has many beneficial effects in language acquisition. The more a person reads, the more they will develop their vocabulary knowledge (Chou, 2011). Reading can also help students improve their spelling and writing skills and facilitates language development (Harmer,1991). Therefore, teaching and strategies reading skills need to 
be improved. Good readers use their experience, titles, and textual clues to expect what is coming in a reading text.

According to Nunan (1988) the aim of reading is comprehension. Reading comprehension refers to reading for meaning, understanding, and entertainment. It involves higher-order thinking skills and is much more complex than merely decoding specific words. In addition, Hancock adds that reading is a very complex process that requires many different skills. Comprehension involves understanding the vocabulary, seeing relationships among words and concepts, organizing ideas, recognizing the author's purpose, evaluating the context, and making judgments (Hancock, 1999).

Since reading is a complex process, Grabe \& Stoller (2004) argues that many researchers attempt to understand and explain the fluent reading process by analyzing the process into a set of component skill. Those are finding topic, main idea, antonym, synonym, reference and inference. Successful reading is determined by the comprehension of the reader in reading process. To gain the purposes, there are some strategies that can be applied by the students in reading, such as highlighting, summarizing, note taking, paraphrasing, etc.

However, there were some problems found in the teaching and learning process related to the students' comprehension on reading. The result of test and interview which had been conducted at first year students of Arabic class at State Institute for Islamic Studies Imam Bonjol Padang proved that reading still was a problem. In fact, most of the students got low score on reading. They felt difficult mostly to find main idea and specific information what text told to the reader. Students were unable to predict what the text about. Research studies show that most university students today take a surface approach to reading and learning (Biggs, 1996). A surface approach to reading is the tacit acceptance of information contained in the text. Students taking a surface approach to reading usually consider this information as isolated and unlinked facts. This leads to superficial retention of material for examinations and does not promote understanding or long-term retention of knowledge and information. They only focus on the sign of the text itself.

This phenomenon occurs because lecturers usually lecture the texts and evaluates students on their retention of facts and principles conveyed in the lectures. In fact, the students do not use higher-order cognitive skills such as the ability to analyze, synthesize, solve problems, and think metacognitively in order to negotiate meanings with the author and to construct new meaning from the text. In other word, the students do not focus on the meaning of the text.

However, in teaching reading, teaching process should help the students to focus on the author's message, the ideas, the line of argument, and the structure of the argument. The students make connections to already known concepts and principles and use this understanding for problem solving in new contexts.

Most of lecturers gave the text to the students and asked them to answer the questions without giving how to find the topic, main idea and other things related to reading. Current methods for teaching comprehension tend to emphasize the products of comprehension, and neglect the processes of comprehension. It is supported by Collins that most of teaching reading is focused on the students' score in answering the test (Collins \& Smith, 1980).

However, lecturers should elaborate students' comprehension on the text through communicative strategies in order to make teaching and learning process is interesting and effective. By using an appropriate strategy, it is hoped that the students' comprehension on the reading will be improved. 
Predict Organize Search Summarize Evaluate (POSSE) is one of strategy that can improve students' comprehension on reading. Predict Organize Search Summarize Evaluate (POSSE) strategy which was developed by Englert \& Mariage (1991) is a mnemonic reading comprehension strategy. It is designed to activate student's prior knowledge about the topic and to link it with new information contained in the text. In addition, this strategy is designed to model habits of strong readers to students and teach them how to utilize these strategies.

This reading comprehension strategy includes many reading practices that have been shown to aid reading comprehension, such as graphic organizers, text structures, stimulation of student background knowledge, and self-monitoring. Arianti \& Tiarina (2014) support this by saying that POSSE is a multistep teaching strategy that not only assists students in activating the prior knowledge, but also encourages them to organize their existing knowledge and structure, and then summarize and elaborate on the connections between what they already knew and what they have learned. The strategy activates prior knowledge, but also encourages students to organize their existing knowledge and then summarize and elaborate on the connections between what they already knew and what they have learned. So, this strategy can be used to overcome students' problem in reading.

POSSE strategy has been proven to be helpful to improve the students' achievement in comprehending reading material and help students to comprehend the text easily at high school levels (Westwood \& others, 2008); (Maha \& Sibarani, 2013); (Gersten, Fuchs, Williams, \& Baker, 2001); (Jitendra \& Gajria, 2011); (Erawati, 2012); and (Sorrells \& Linan-Thompson, 2005). However, these researches have not been focused on students' comprehension on components of reading comprehension yet. In addition, this research was conducted to enhance students' reading comprehension by using Predict Organize
Search Summarize Evaluate (POSSE) and to find out the effect of POSSE on students' reading components at first year students of Arabic class at State Institute for Islamic Studies Imam Bonjol Padang, By conducting this research, it is expected that the students gain essential perspective about the importance of getting knowledge a text.

\section{METHOD}

A quasi experimental research was used to conduct this research at Arabic classes at Adab Faculty of State Institute for Islamic Studies Imam Bonjol Padang. An experimental research is the only type of research that can test hypotheses to establish cause and affect relationships. The group that receives the treatment is often called the experimental group while the other group without treatment is the control group (Gall, Borg, \& Gall, 2003). Two classes of active students at second semester in academic year 2015/2016, who were clustered randomly selected, participated on this research (Sugiyono, 2008). There were 30 students for each group. Before and after giving treatment, the students were given pre test and post test. One group pre test-post test control group design was used to conduct the research (Fraenkel, Wallen, \& Hyun, 1990); (Creswell, 2009). Both classes have the same topic, the same length of time.

The data of this research were students' achievement on all components of reading comprehension. Observation was used to search and collect all information from the lecturers in teaching English. Interview was used to support the data collected. Structure non participant was used to observe the students and teachers activities in learning activities (Creswell, 2013) Interview was used to support the data collected.

The instrument of this research was reading test. Multiple choice which was proposed by Brown (Abeywickrama \& Brown, 2010) was used to test students' reading comprehension. The indicators were 
used to assess students' reading comprehension were topic, main idea, reference, antonym and synonym, location information, and inference (Abeywickrama \& Brown, 2010).

Quantitative analysis was used to describe the effect POSSE strategy in improving students' reading comprehension and analyze the gain score of experimental and control groups by using t-test. All the data were input into the computer, and then analyzed through the Statistical Package for Social Science (SPSS 17.0). To be more specific, firstly, descriptive statistics such as frequencies means, and standard deviations were computed.

\section{RESULTS AND DISCUSSION}

The implementation of POSSE strategy at Adab Faculty of State Institute for Islamic Studies Imam Bonjol Padang gave significant effect toward students' comprehension on reading at experimental class. It can be seen from the students' scores on the following tables below:

Table 1. Data Description of Pre Test and Post Test at Experimental and Control Class

\begin{tabular}{lllll}
\hline Desc & \multicolumn{3}{c}{ Pre-test and Post test } \\
& \multicolumn{2}{c}{ Control Group } & \multicolumn{2}{c}{ Experimental Group } \\
& pre-test & post-test & Pre Test & Post test \\
\hline Resp & 30 & 30 & 30 & 30 \\
Mean & 60.53 & 64.66 & 66.93 & 72.26 \\
\hline
\end{tabular}

Table 2. Data Description of Gain Score Both Experimental and Control Class

\begin{tabular}{|c|c|c|}
\hline \multirow[t]{3}{*}{ Description } & \multicolumn{2}{|c|}{ Experimental and Control Classes } \\
\hline & Experimental Class & Control Class \\
\hline & Group A & Group B \\
\hline Respondent & 30 & 30 \\
\hline Median & 4.00 & 4.00 \\
\hline Mean & 5.60 & 4.27 \\
\hline
\end{tabular}

Table 3. Component of Reading Comprehension can be Improve by Predit Organize Search Summarize Evaluate Strategy

\begin{tabular}{|c|c|c|c|c|}
\hline No & $\begin{array}{l}\text { Reading of } \\
\text { evaluation }\end{array}$ & $\begin{array}{c}\text { Before } \\
\text { treatment }\end{array}$ & $\begin{array}{c}\text { After } \\
\text { Treatment }\end{array}$ & $\begin{array}{c}\text { Mean } \\
\text { Gain } \\
\text { Score }\end{array}$ \\
\hline 1 & Topic & 12.53 & 16.4 & 3.87 \\
\hline 2 & Main Idea & 10.53 & 13.5 & 2.97 \\
\hline 3 & $\begin{array}{l}\text { Word } \\
\text { reference }\end{array}$ & 10 & 10.66 & 0.66 \\
\hline 4 & $\begin{array}{l}\text { Location } \\
\text { Information }\end{array}$ & 10.53 & 11.2 & 0.67 \\
\hline 5 & $\begin{array}{l}\text { Synonym } \\
\text { Antonym }\end{array}$ & 11.46 & 11.73 & 0.27 \\
\hline 6 & Inference & 8.76 & 8.93 & 0.17 \\
\hline Mean & Score & 63.81 & 72.42 & 8.61 \\
\hline
\end{tabular}

The table above could be explained that the students' reading comprehension on reading components before giving the treatment was means score 63.81. After giving treatment with POSSE strategy, the students' achievement on reading comprehension was 72.42. The following table was the hypothesis testing.

Table 4. Hypothesis Testing of POSSE Strategy on Reading Comprehension

\begin{tabular}{|c|c|c|c|c|c|c|}
\hline \multirow[t]{2}{*}{ No } & \multirow{2}{*}{$\begin{array}{c}\text { Hypo- } \\
\text { thesis (Ha and } \\
\text { H0) }\end{array}$} & \multicolumn{2}{|c|}{$\begin{array}{c}\text { Gain Mean } \\
\text { score }\end{array}$} & \multirow[t]{2}{*}{$\begin{array}{c}\text { t-test } \\
(\alpha=0,05)\end{array}$} & \multirow[t]{2}{*}{ Finding } & \multirow[t]{2}{*}{ Conclusion } \\
\hline & & Exp & Cont & & & \\
\hline & $\begin{array}{c}\left.\mathrm{Ha}_{1}: \mu \mathrm{A}_{1} \neq \mu \mathrm{A}_{2}\right) \\
\left(\mathrm{H} 0_{1}: \mu \mathrm{A}_{1}=\mu\right. \\
\left.\mathrm{A}_{2}\right)\end{array}$ & 5.60 & 4.27 & $\begin{array}{c}\mathrm{t}-_{\text {count }}=3.61 \\
\mathrm{t}-_{\text {table }}=1.67 \\
\mathrm{p}-\mathrm{value}= \\
0,00\end{array}$ & $\begin{array}{l}\text { t-counted } \\
>\text { t-table } \\
\text { p-value } 0,00<(\dot{\alpha}= \\
\quad 0,05) \\
\mathrm{Ha}_{1} \\
\text { accepted }\end{array}$ & $\begin{array}{l}\text { POSSE strategy is more effective } \\
\text { than the conventional one in } \\
\text { teaching reading comprehension }\end{array}$ \\
\hline
\end{tabular}

The result of t-test showed that the value of t-calculated was 3.61 while the criteria value of t-table at degree of freedom 58 and the level of significance 0.05 , $t$-table is 1.67. In conclusion, the value of $\mathrm{t}$-calculated is greater that the value of t-table. It means the hypothesis was accepted. So, it could be concluded that teaching reading by Predict Organize Search Summarize Evaluate Strategy could be better enhance the students' 
reading comprehension at Arabic class. In addition, this strategy is better enhancing reading component on finding topic.

Based on the result of the research, it was found that POSSE strategy can enhance the students' reading comprehension at Arabic class of Islamic Studies Imam Bonjol Padang. In fact, most of the students are unable to understand particular words, particular sentences, relations between sentences, and the text fits together as a whole.

Reading comprehension involves higher-order thinking skills and is much more complex than merely decoding specific words that requires many different skills. In addition, comprehension involves understanding the vocabulary, seeing relationships among words and concepts, organizing ideas, recognizing the author's purpose, evaluating the context, and making judgments (Hancock, 1999).

POSSE strategy is a reading comprehension strategy that incorporates reading and learning practices that effective readers and learners use automatically (Englert \& Mariage, 1991). By using this strategy, the students can discuss their reading through predicting organizing searching summarising and evaluating to comprehend text. The strategy activates prior knowledge, but also encourages students to organize their existing knowledge and then summarize and elaborate on the connections between what they already knew and what they have learned.

POSSE has five main strategies, namely predict ideas from prior knowledgee of the text, organize predictions based upon the forth coming text structure, search and summarize for main ideas within the text structure and evaluate comprehension. These steps were implemented on reading process. The steps on POSSE strategy can encourage students' comprehension on reading. The first step of POSSE is to provide the students with sheet and explain how the sheet highlights each step in the strategy and includes concept or thinking maps to help them organize their thoughts. Show students that the strategy sheet is divided into two activities to complete before reading (predict and organize background knowledge) and three activities to complete during and after reading. The steps can be elaborated as the following explanation. The teacher activate background knowledge by brainstorming what the text will be about using text clues such as the title, headings, pictures/diagrams or initial paragraphs. The teacher can also guide students in the prediction step by asking question like (what do you think about the text). This question can encourage the students to be aware of their own metacognitive processes. Prediction involves essential steps such as what evidence readers have found in the text and what personal experiences they have got, and what justifications can be proposed about their predictions (Day \& Jeong-suk, 2005). Pressley and Harris (2008) have found that the predictive power in reading a text plays a vital role in comprehension. To encourage the students' knowledge on reading text, graphics help readers predict, guess, relate new knowledge to prior knowledge, understand the text, and retrieve words from their memories. For example, graphic representations help readers find relationships and connect ideas to make them less abstract. Graphics can be represented by diagrams, spider maps, semantic maps, hierarchical organizer, comparative organizer, Venn diagrams, cause and effect organizers, plot chart, and story frame. There has been evidence that graphic representations are so helpful for those with learning disabilities and reading difficulties by visualizing relationships among structural elements in a text. It is clear that the prediction step has the purpose to active the students' prior knowledge while doing the brainstorming activity.

The second step is the students arrange their brainstormed ideas in the prediction step into a semantic map. Semantic mapping activity has the purpose to introduce 
key terms, activate prior knowledge, and as a pre-assesment. The students prepare themselves for reading and the teacher also discusses with students what new ideas they have learned about the topic.

The third step is the students arranging their brainstormed ideas in the prediction step into a semantic map. Semantic mapping activity has the purpose to introduce key terms, activate prior knowledge, and as a preassesment. The students prepare themselves for reading. The teacher also discusses with students what new ideas they have learned about the topic.

The fifth step is the students begin reading the text. The students also search for the main idea of the text in each paragraph. The teacher tells the students to read the text carefully to confirm their predictions about the ideas in the text. The sixth step is summarizing activity. The students summarize the text. In summarizing the text, the students required to identify the key idea of each paragraph. Research has found that summarizing not only improves comprehension but it also enriches the readers' vocabulary when exposing to a huge online encounters (Duke, Pearson, Farstrup, \& Samuels, 2002). It should be noted that summarizing helps readers delete unnecessary and redundant information, compose words and paragraphs to replace original texts, and then produce new paragraphs.

The last step is evaluation. The students evaluate their understanding by doing the comparing. The students compare the two semantic maps generated before reading the text with the semantic map that is completed after the reading of the passage. The teacher asks the students to find the new words from the text and their meanings.

It can be seen that activities on POSSE can inspire students to call up their prior knowledge gained within previous stages; involve checking the new information against prior knowledge and seeing if this makes sense based on their previous knowledge; and check for growth or any changes in their new knowledge by finding out what they actually have learned during this process.

Based on the data analysis, it showed that there is significantly effect. It means that teaching reading by using Predict Organize Search Summarize Evaluate Strategy can enhance students' reading comprehension statistically was accepted. Concerning to the result of t-test calculation in both groups, it can be concluded that Predict Organize Search Summarize Evaluate Strategy can develop students' reading comprehension.

\section{According to Englert \& Mariage} (1991) POSSE strategy is a reading comprehension strategy that incorporates reading and learning practices that effective readers and learners use automatically. Students discuss their reading and use the strategies of predicting organizing searching summarising and evaluating to comprehend informational or expository text. The strategy activates prior knowledge, but also encourages students to organize their existing knowledge and then summarize and elaborate on the connections between what they already knew and what they have learned.

This strategy can improve students' comprehension on finding topic of reading comprehension components. There are six reading comprehension components that should be mastered by the students namely; topic, main idea, word reference, location information, synonym and antonym and inference (Nunan 1988). The topic is the one thing a paragraph is about. Every sentence in a paragraph in some way discusses or explains the topic. Think of the topic as the subject of the entire paragraph. Finding the main idea is the main point or the central thought of the reading selection. It is usually complete sentence that includes the gist of every idea from the paragraph. An efficient reader understands not only that idea but also the relative significant as express by the outdoors. In other words, some of the ideas are super ordinate while other is subordinate. Recognizing supporting detail are those facts 
and ideas that prove for explain the main idea of paragraph. In addition, finding topic relates to finding actual information that requires reader to scan specific details, actual information begins with WH question words. In finding inference of idea in text, writers however do not write out everything they expected the reader to understand to do. So, it is often not necessary and sometimes not desirable from the writer's point of view. Writer use language efficiently and recognize what can be inferred from their sentences. In other words, ab efficient reader is able to understand those implications.

It would be helpful if POSSE strategy adopted to gain the students' comprehension on reading at State Institute for Islamic Studies Imam Bonjol Padang. It is one of teaching reading strategies that has improved students' comprehension on reading in English. It implies that lecturers should be active to create strategies or techniques in order improve students' skills in English.

\section{REFERENCES}

Abeywickrama, P., \& Brown, H. D. (2010). Language assessment: Principles and classroom practices. NY: Pearson Longman.

Arianti, G., \& Tiarina, Y. (2014). Teaching reading analytical exposition text to senior high school students by using posse (predict, organize, search, summarize, evaluate) strategy. Journal of English Language Teaching, 3(1), 195-201.

Biggs, J. (1996). Enhancing teaching through constructive alignment. Higher Education, 32(3), 347-364. https://doi.org/10.1007/BF00138871

Chou, P. T.-M. (2011). The effects of vocabulary knowledge and background knowledge on reading comprehension of Taiwanese EFL students. Electronic Journal of
Foreign Language Teaching, 8(1), 108-115.

Collins, A., \& Smith, E. E. (1980). Teaching the process of reading comprehension. Center for the Study of Reading Technical Report; No. 182.

Creswell, J. W. (2013). Research design: Qualitative, quantitative, and mixed methods approaches. Sage publications.

Day, R., \& Jeong-suk, P. (2005). Developing reading comprehension questions. Reading in a Foreign Language, 17(1), 60 .

Duke, N. K., Pearson, P. D., Farstrup, A. E., \& Samuels, S. J. (2002). What research has to say about reading instruction. What Research Has to Say about Reading Instruction.

Englert, C. S., \& Mariage, T. V. (1991). Making students partners in the comprehension process: Organizing the reading "POSSE." Learning Disability Quarterly, 14(2), 123-138.

Erawati, N. L. P. E. P. (2012). A comparative effect of metacognitive selfmonitoring strategies on students'reading competency based on text types. Jurnal Pendidikan Bahasa, l(1).

Fraenkel, J. R., Wallen, N. E., \& Hyun, H. H. (1993). How to design and evaluate research in education (Vol. 7). McGraw-Hill New York.

Gall, M. D., Borg, W. R., \& Gall, J. P. (1996). Educational research: An introduction . Longman Publishing.

Gersten, R., Fuchs, L. S., Williams, J. P., \& Baker, S. (2001). Teaching reading comprehension strategies to students with learning disabilities: A review of research. Review of Educational Research, 71(2), 279-320. 
Grabe, W., \& Stoller, F. L. (2004). Teaching reading. The Encyclopedia of Applied Linguistics.

Hancock, J. (1999). The Explicit Teaching of Reading. ERIC.

Harmer, J. (1991). The practice of English language teaching. London/New York.

Jitendra, A. K., \& Gajria, M. (2011). Reading comprehension instruction for students with learning disabilities. Focus on Exceptional Children, 43(8), 1.

Maha, E. R., \& Sibarani, B. (2013). The Effect of Applying POSSE (PredictOrganize-Search-Summarize-

Evaluate) on the Students' Reading Comprehension. GENRE Journal of Applied Linguistics of FBS Unimed, 2(1).

Nunan, D. (1988). The learner-centred curriculum: A study in second language teaching. Cambridge University Press.

Pressley, M., \& Harris, K. R. (2008). Cognitive strategies instruction: From basic research to classroom instruction. The Journal of Education, 189(1/2), 77-94.

Sorrells, A. M., \& Linan-Thompson, S. (2005). Case studies of resource room reading instruction for middle school students with high-incidence disabilities.

Sugiyono, P. D. (2008). Metode Penelitian Pendidikan. Bandung: Alfabeta.

Westwood, P., \& others. (2008). Interventions for Reading. What Teachers Need to Know about Reading and Writing Difficulties, 42. 